\title{
The Symbol of Cosmetic Products as Social Distinction and the False Needs of Shopping for Cosmetics at Department Stores Aroused by Women's Magazines
}

\author{
Gulcin Ipek Kalender \\ Communication Sciences Faculty, Department of Communication Design and Management, Anadolu University, Eskisehir, \\ Turkey \\ Email: giemeksiz@anadolu.edu.tr
}

How to cite this paper: Kalender, G. I. (2021). The Symbol of Cosmetic Products as Social Distinction and the False Needs of Shopping for Cosmetics at Department Stores Aroused by Women's Magazines. Advances in Journalism and Communication, 9, 1-11.

https://doi.org/10.4236/ajc.2021.91001

Received: December 28, 2020

Accepted: March 5, 2021

Published: March 8, 2021

Copyright $\odot 2021$ by author(s) and Scientific Research Publishing Inc. This work is licensed under the Creative Commons Attribution International License (CC BY 4.0).

http://creativecommons.org/licenses/by/4.0/

\begin{abstract}
Cosmetic industry is a dynamic sector, which changes fast with the emergence of new products that are advertised glamorously, and they take place on colorful pages in women's magazines, which imply to the average female consumer that they can always create a new self by purchasing these cosmetic products. In other words, in the consumer culture, the products that they purchase define consumers, and consumption is seen as an everyday activity, which is done quite frequently (Paterson, 2006). The cosmetic products that women decide to buy carry symbolic meanings, and these meanings are transferred when they consume these products (Iqani, 2012). The consumer culture promises to the female consumer that by buying a variety of goods she can achieve self-enhancement, which will help her to stand out among other people, and she can preserve her self-esteem this way as she will be superior to others (Mooij, 2004). Therefore, this paper aims to make a critique of the consumer culture from the perspective of cosmetic products by showing how women, in fact, use cosmetics as a symbol of distinction and do hedonic shopping at department stores, and how women's magazines indeed create false needs in their readers for purchasing more cosmetic products by putting a literature review forward.
\end{abstract}

\section{Keywords}

Make-Up, Cosmetic Products, Social Distinction, Shopping, Department Stores, and Women's Magazines 


\section{Introduction}

Wearing make-up is a favourite activity for many women worldwide because it makes women feel alluring and charming. Generally, women compare themselves with other women in terms of their appearance and if they believe that they will turn into a new person that they desire and become attractive, they use cosmetics products (Rudd, 1997). Therefore, the main reason why women prefer to use cosmetic products worldwide is that they want to increase their physical attractiveness and to have a better perception of their body image, which makes them feel confident about themselves (Guthrie et al., 2008).

Make-up is considered a feminine activity because while women apply a variety of products to their faces and bodies, it is a kind of daily ceremony for them, which is relaxing and pleasurable. While using cosmetics products, women physically and psychologically transform themselves and they do this in certain intervals that eventually become a routine and a ritual (Rudd, 1997). Women like to see the change in their faces and bodies after they use cosmetics products because it makes them feel content about their physical appearance.

Some women wear make-up for cultural reasons such as the women in Eastern cultures, while other women wear make-up to look elaborate in daily life such as the women in Western cultures. The reason behind this is that while Western cultures emphasize individualism, Eastern cultures give importance to collectivism (Madan et al., 2018). For instance, in Japan, the elite people do traditional make-up as a celebration of women's turning mature by wearing red lips and a white face (Live Japan, 2019).

On the other hand, in Western cultures, among all of the cosmetic products that she tries, lipstick has special importance for a woman. In fact, lipstick is the first cosmetic product that most women have used in their life. For instance, in the U.S.A, girls start to wear lipstick while they are around 14 to 18 years old, and even though their parents don't permit them to wear it, they wear it when they go outside or go to a friend's house (Clarke \& Bundon, 2009). Also, the researches indicate that women use their lipstick more in public and thus the brand of their lipstick is more visible compared to the other cosmetic products, and thus women use their lipstick as a status symbol more (Chao \& Schor, 1998).

Women magazines, which are an entertaining way to spend leisure time for many women, mainly turn around the topics of fashion and beauty, and these magazines usually advertise various cosmetic products, which are luxurious and chic along with stylish apparels. Indeed, fashion is all about the time that we are living at that moment, it is defined with the word "zeitgeist", which is about seizing the day and it defines a season, and thus fashion, which continually changes and which doesn't remain the same, is mainly used in order to symbolize a particular status and social class, and it is a self-expression for the individual (Jackson \& Shaw, 2009). Therefore, women's magazines continually demonstrate the change in fashion, which mainly appeals to sophisticated classes by including the cosmetic products displayed on department stores on their pages. 
This research on cosmetics has a few purposes from different angles. First of all, it aims to show cosmetic products' effect in women's lives in terms of signifying social distinction, secondly it aims scrutinize contemporary women's magazines' role in arousing "false needs" for purchasing more cosmetic products in their readers, and lastly it aims to demonstrate women's hedonic wish to shop for more cosmetic products at department stores with the influence of false needs. With this aim, a critical literature review is put forward.

\section{The Method of the Research}

This research is a qualitative one, in which the method of literature review is used. A qualitative research tries to understand how situations and particular occurrings in a certain topic are connected to each other during the progression and how they influence each other in the meantime, and thus it always includes the process of interpretation and explanation (Maxwell, 2018). The researcher first makes a catalogue search in the library of her university with the help of some keywords that are specific to her research and determines some books and articles that are relevant for her research. In the literature review, the researcher first determines which sources that she wants to examine and after getting help from the bibliography of these sources, she precedes into the next one and delves into a larger field (Merriam, 2018).

According to Creswell (2002) thanks to the literature review, the researcher first assesses the data that she has received from different sources such as books or articles etc. according to the topic that she researches, and then she cites the significant ones for her research, following that she highlights the main questions for her research, and finally she gives a reasoning and justification for the her own results. Therefore, with the method of literature review, the literature on this topic is combined and criticized from the perspective of the researcher, and this way the researcher puts the strengths and weaknesses in the literature about this topic from her own interpretation (Merriam, 2018).

\section{The Cosmetics Products Signifying Social Distinction}

The cosmetic industry is a part of the commercial or consumer culture since it is based on advertisements aiming to sell a product (McAllister, 2003). During their lifespan, people are in the process of consuming continually and they cannot exist without consuming because consuming is about meeting needs and people will have diverse needs as long as they live (Odabaş1, 1999).

The consumer society promises today's consumers that they will add certain positive characteristics to their social identity with the symbols shown on the brands that they consume, but these people are indeed given short-term goals instead of long-term ideals in life because this short-term goal is defined as shopping which is about satisfying the longing feelings that one desires for particular products (Dağtaş \& Dağtaş, 2019). Therefore, this is the era of exchange of meanings with symbolic consumption, and these symbols are shown with the 
fabulous products presented on the pages of women's magazines. Therefore, advertisements on women's magazines often try to convince consumers to buy more products by drawing attention to their needs, but sometimes these can be "false" needs mainly serving the purpose of hedonic shopping, as well.

Today, women are considered significant consumers because of their huge amount of spending in the market and they not only do utilitarian shopping aiming to meet their first needs, but they also do hedonic shopping in order to have a pleasant feeling, and they fulfil their fantasies about purchasing and trying different consumer products (Huddlestone \& Stella, 2011).

In fact, commercial culture is a part of popular culture. Popular culture always creates myths and rituals and produces a fantasy within real life with the simple and easily reachable products produced with serial production and whose life span is very short (Çakır, 2014). Therefore, cosmetic products are a part of popular culture, as well.

All of the cosmetic products are advertised with glamorous fantasies promising to make a change in the physical appearance of women, they are easily reachable within the cosmetic stores that allow women to test the products before purchasing at shopping malls, and their life span is short as they are disposable. Women often tend to do hedonic shopping of cosmetic products at department stores because they have a fun time during their leisure time by observing the new fashion trends and they find something that might appeal to them for purchase and they have a pleasurable time while trying the testers with the help of salespersons (Huddlestone \& Stella, 2011).

Consumer culture makes women search for a "good life" by making them desire the goods that they want to purchase more and more at department stores, while in the meantime it makes women search for a "body perfect" by putting unachievable body images in front of them on the pages of women's magazines, as well as, creating dissatisfaction about their own bodies (Dittmar, 2008).

The women who feel the constant desire to purchase another cosmetic product or apparel right after she has already bought one is actually manipulated by the consumer culture which is about the ceaseless mass production of standardized commodities because her "wants" turns into "false needs" all of a sudden (Paterson, 2006).

Nevertheless, these women who do hedonic shopping for cosmetics cannot fulfill their satisfaction completely because their desires are continually delayed, they often daydream about the products when they look at women's magazines, and when they purchase a cosmetic product, their satisfaction lasts short, and it passes quickly, and they want to look for another product unconsciously with the emergence of a new desire (Paterson, 2006).

Thus, together with the popular culture, advertisements on women's magazines obscure the line between reality and dream and they influence the consciousness of the viewer by awakening a desire and create false needs for them by manipulating their senses. 


\section{The Symbolic Meaning of Cosmetic Products}

In the consumer culture, each product that we choose to buy for ourselves related with our taste after being affected from advertisements is, in fact, a meaningful choice because it determines our lifestyle (Jagger, 2000). Thus, while purchasing cosmetic products, women actually seek an identity because they create their ideal self with each product that they purchase showing their social status (Dittmar, 2008). As a result, consumer culture sees the woman body as a project, on which women need to work with their preferences of products (Richardson \& Locks, 2014). On the other hand, these products are already displayed on the pages of women's magazines and they are not only categorized, but also recommended according to the taste of editors who lead the followers.

In other words, women engage in a symbolic consumption with the products that they decide to buy and their consumption habits define who they become (Jagger, 2000). Some of the women buy cosmetic products in order to show their status, and thus income, occupation, education, and urban residence are some of the main factors that have an effect on women's purchase behaviours of cosmetic products (Chao \& Schor, 1998).

The symbolic consumption, which is motivated by advertisements, is a construction of self-identity because it shapes women's class and their consumption habits show who they are to the other people (Jagger, 2000). Russell (2012) mentions that women use cosmetics for two main purposes, which are beautification and signification, and while beautification means making the body more attractive by adorning it, signification means using the cosmetic products as a sign of class and rank in society.

Consumption is a part of production in the sense that women not only consume cosmetic products for their daily needs, but they also create an identity with the help of these goods (Stillerman, 2015). Women culturally become the producer of new meanings and of pleasures with the cosmetic products that they use (Fiske, 2010). Women transform their bodies to the perfect ones; their selves to the ideal selves and their lives to the good lives by purchasing the cosmetic products that are advertised presenting a stylish and fabulous lifestyle (Dittmar, 2008).

For instance, in the U.S.A, American women living in the urban parts of the city tend to buy more expensive cosmetic products compared to less educated women living in the suburban parts of the city as they use cosmetic products as a sign of social status (Nash et al., 2006). According to the approach of Weber, first upper class women consume the luxurious cosmetic products and the trendy fashion that comes along with it and these women use these expensive products to show their superiority over other women; however once these goods become widespread with their cheaper versions and can be reachable by middle class women, then the cosmetic industry puts forward new ones to the market by creating new trends (Stillerman, 2015). 


\section{The Way Cosmetic Products Are Introduced in Women's Magazines}

The fashion of cosmetics, which is dealt with in many editorial pages in women's magazines, is indeed about categorizing people in different classes as women in higher social classes show their distinction with the expensive cosmetic products that they purchase while the women in lower classes imitate them with their cheaper versions, however, for elite women to protect their social status permanently, new high-fashion cosmetic products need to be released to the fashion market continually; otherwise, these women cannot show their distinction and cannot differentiate themselves from the lower classes evidently (Paterson, 2006).

This gap is explained with the term "social distance" as women in the upper classes use cosmetic products to demonstrate their social rank, and they distance themselves from lower classes this way (Reilly, 2014). Therefore, women's magazines usually show images of luxurious cosmetic products such as perfumes by creating amazement in the average female consumers.

Women's magazines create false needs in their female readers by motivating them to purchase more goods that they don't actually need and create a desire for shopping, which can't be totally satisfied (Paterson, 2006). While reading women's magazines, women crave for reaching to something either stylish clothes or a cosmetic product beyond that their reach at that moment, and thus they need to give an effort to reach that ideal, and if there are no ideals then women don't need the necessity of giving an effort (Hoskins, 2014).

According to Küçükerdoğan (2009), cosmetic advertisements in women's magazines motivate women to shop a variety of products because they lead women to hedonism, which is about getting pleasure from the act of shopping, and to enjoy possessing something and feel psychology relieved because of having it, and at the same time they feel themselves belong to a specific social class within the society by actualizing what the advertisement presents them as a dream and having the product enables them to show their difference from other people in the society. Therefore, they go to shopping to the department stores to satisfy these emotions.

\section{The Department Store as "Retail Therapy"}

The idea of a department store is that the consumer doesn't have to feel the obligation of buying a product when she enters the store; instead, it is about wandering around by looking at different alternatives of products that she visualizes that they will look good on her (Corrigan, 1997). In a way, women want to shop because it is a "retail therapy" for them which is relaxing, pleasurable and it gives them happiness and elevates their moods, and they express their identity with the goods that they purchase and so they exist with the slogan "I shop, therefore I am" (Dittmar, 2008).

Every female consumer has her own taste in shopping, thus she is free to 
choose anything that will help to create her self-image among the abundance of cosmetic products displayed in department stores (Schroeder, 2002). On the other hand, there is probably a reason why she makes that choice either consciously or unconsciously, thus what she wears says particular things about her in a sociological aspect (Bradford, 2015).

The department store offers women a shopping atmosphere, which they discover by looking at the new products while getting pleasure from the activity of window-shopping. Strahle and Hohls (2018) mention that one of the reasons why women would like to come to the department store is that they want to explore the place for the first time, and these women want to walk around the decorated area while listening to the popular foreign music playing loudly at the background arousing their senses.

The department stores usually have experienced make-up artists, which give free make-up to women with sample cosmetic products and who try to persuade them to buy the cosmetic products used during make-up afterwards by giving special promotions. Women who have a pleasurable time when make-up is done to their faces and who see the change on their faces by recognizing that they have become alluring want to purchase the cosmetic products right after. In that sense, purchasing cosmetics, which is about the consumer culture, involve many activities such as entertainment and leisure within (Iqani, 2012).

According to Strahle and Hohls (2018) this shopping atmosphere that is the department store provides certain ambiance within such as music, scent, lighting, window-display, furnishing, and color, and it gives the consumers particular messages about the identity of the brand, while they prompt the instinct of shopping in women since the popular foreign music at the background in the department stores subtly make women to stay in the department store longer hours by motivating them to spend more time there.

In other words, the department stores at shopping malls usually try to pull consumers to their cosmetic corners with loud foreign pop music, which gives a sense of dynamism by motivating women to shop or with ornamented decorations in special days, which draw the interest of women by making them impressed (Stillerman, 2015).

The cosmetics industry is a major sector. The aim of the cosmetic advertisements is to sell products and they tell women that in order to achieve perfection they need to consume these products all the time (Pompper, 2017). For instance, the advertisements in women's magazines frequently show the products which are must-have essentials and create a desire for women to purchase them immediately by saying that "she's gotta have it" (Jagger, 2000). The cosmetic industry put women in a rush of consuming a variety of cosmetic products in order to look better and they usually do that by tempting women with the advertisements in women's magazines and at shopping malls with the cosmetic stands that they open with experienced salespersons.

The false needs that are created by women's magazines tempt women to pur- 
chase more material goods at the department stores that are definitely not a part of their biological needs and thus women, who feel the urge to buy more cosmetic products and who are defeated by their desire, are in fact not savvy consumers; instead, these women act with their impulses, and they are irrational (Paterson, 2006). On the other hand, women who buy these products, which are advertised, not only construct their identities as they define themselves with their choices of goods; but also they get pleasure from the product that they buy (Dittmar, 2008). Therefore, women who shop to satisfy their desires are classified as hedonic shoppers because these women get excitement, pleasure, and fun out of the activity of shopping, and they nurture their psychological emotions this way (Yurchisin \& Johnson, 2010).

Moreover, some of the women who want to show their superiority to others are inclined to buy more expensive cosmetic products therefore when they go to the department store, they first go to the higher-priced brands' section as they think that the higher the price is better because it is an expression of a higher status and this is explained as the Veblen effect, or conspicuous consumption, which means that the higher price increases the demand more (Bögenhold \& Naz, 2018).

\section{The "Perfect Body" and Using Cosmetics}

Using cosmetic products are presented as a solution for reaching the best body and the ideal beauty, and women's magazines usually associate cosmetic products with materialism and pursuit of happiness. Women think that the more they use cosmetic products, the more they will be liked by other people, especially by the opposite sex, and they can get rid of their relationship problems in their social lives this way because being beautiful will solve many things in their lives.

In Westernized cultures, in order to draw the attention of men, women who want to represent the idealized femininity need to preserve the form and size of their slim bodies by spending time and money on physical exercise, diets, cosmetic surgery, and cosmetics products, and this way they are implied that they will normalize their appearance (Pompper, 2017). The cosmetic industry constantly reminds women through advertisements that women should always care their bodies and thus women should be occupied with dieting to get into shape, wearing make-up to look more feminine, and dyeing their hair to look younger (Hoskins, 2014).

On the other hand, there isn't a fixed definition of attractiveness as it changes according to the culture that it is founded by. For instance, while the American women are more concerned with their body image from early ages, the women in Eastern cultures such as the Japanese give more importance to the inner beauty instead of the physical (Mooij, 2004). However, the Western advertisements taking place on many contemporary women's magazines mostly give value to the ideal white beauty, which is about the slenderness of the feminine physical body. 


\section{Conclusions and Discussions}

Due to the wide acceptance of ideal white beauty, many women worldwide engage in purchasing the cosmetic products that they see on the pages of women's magazines to give themselves an alluring out-look and to pursue a good lifestyle. In fact, women's magazines usually awaken false needs in their readers because they often portray a dreamlike lifestyle. Women magazines usually lead many women to conspicuous consumption of cosmetic products so that these women can show their social distinction from the rest, can separate themselves as higher status, can protect their self-esteem this way as Mooij (2004) indicated, and can have the experience and taste of an upper-class lifestyle.

According to Dağtaş and Dağtaş (2019), today we live in the "culture industry" that the Frankfurt School thinker Adorno pointed out, and people need leisure time so that they can spend pleasurable hours at department stores, and this in turn not only creates profits for the retail sector, but it also creates new opportunities for the mass communication tools such as the women's magazines.

Therefore, women magazines continually introduce the most marketable fashion trends, which change every fall and spring, and it creates discomfort in average women about using this year's cosmetic products that they already have on their chiffoniers as these magazines imply that these cosmetic products have already become old-fashioned and thus women need to go shopping again to amend their appearance (Yurchisin \& Johnson, 2010). Therefore, women who want to keep pace with the season's trends need to go to the department stores to discover the new styles. Thus, women's magazines, in fact, create a basis for the shopping atmosphere at department stores.

Furthermore, women who want to have that pleasant feeling, do shopping for cosmetics during their leisure time as a way of "retail therapy" as Dittmar (2008) pointed, but sometimes this shopping can turn into an irrational activity, as well. Thus, women who are categorized as irrational often go window shopping at department stores in their free time, they either window-shop or they purchase more clothes or cosmetic products that they don't actually need, they gaze at the products in women's magazines with excitement, they continually surf on the websites of fashion brands on the internet, or they browse through the branded content of fashion brands on social media from their mobile phones. In fact, today contemporary way of consumption is a visual kind of consumption because the female consumer constantly looks at the products through seeing, gazing, window shopping, and by viewing the digital images on the web and the social media via their laptop and mobile phone screens (Schroeder, 2002).

All of the false needs aroused mainly by women's magazines lead many women to hedonic shopping at department stores for relieving themselves psychologically and emotionally, and for the aim of reaching social distinction. Consequently, the magazine constructs the world that they expect their readers to live in and they construct the female identities that they expect their readers to conform while they provide entertainment and leisure within their pages. 
Therefore, the magazine creating an admiration for the white ideal beauty is in fact a product of the consumer culture and it basically helps the circulation of goods in the capitalist system.

\section{Conflicts of Interest}

The author declares no conflicts of interest regarding the publication of this paper.

\section{References}

Bögenhold, D., \& Naz, F. (2018). Consumption and Lifestyles. Cham: Palgrave Pivot. https://doi.org/10.1007/978-3-030-06203-3

Bradford, J. (2015). Fashion Journalism. Oxon: Routledge. https://doi.org/10.4324/9780203130865

Çakır, M. (2014). Görsel Kültür ve Küresel Kitle Kültürü. Ankara: Ütopya Yayınevi.

Chao, A., \& Schor, J. B. (1998). Empirical Tests of Status Consumption: Evidence from Women's Cosmetics. Journal of Economic Psychology, 19, 107-131. https://doi.org/10.1016/S0167-4870(97)00038-X

Clarke, L. H., \& Bundon, A. (2009). From "The Thing to Do" to "Defying the Ravages of Age": Older Women Reflect on the Use of Lipstick. Journal of Women \& Aging, 21, 198-212. https://doi.org/10.1080/08952840903054757

Corrigan, P. (1997). The Sociology of Consumption. London: Sage Publications.

Creswell, J. W. (2002). Educational Research. Planning, Conducting, and Evaluating Quantitative and Qualitative Research. London: Pearson Education.

Dağtaş, B., \& Dağtaş, E. (2019). Tüketim Kültürü, Yaşam Tarzları, Boş Zamanlar ve Medya Üzerine Bir Literatür Taraması. In B. Dağtaş, \& E. Dağtaş (Eds.), Medya, Tüketim Kültürü ve Yaşam Tarzları (pp. 27-75). Ankara: Ütopya Yayınevi.

Dittmar, H. (2008). Consumer Culture, Identity and Well-Being. The Search for the "Good Life" and the "Body Perfect". New York: Psychology Press. https://doi.org/10.4324/9780203496305

Fiske, H. (2010). Understanding Popular Culture. New York: Routledge. https://doi.org/10.4324/9780203837177

Guthrie, M., Kim, H. S., \& Jung, J. (2008). The Effects of Facial Image and Cosmetic Usage on Perceptions of Brand Personality. Journal of Fashion Marketing and Management: An International Journal, 12, 164-181.

https://doi.org/10.1108/13612020810874863

Hoskins, T. E. (2014). Stitched Up. The Anti-Capitalist Book of Fashion. London: Pluto Press. https://doi.org/10.2307/j.ctt183p0z0

Huddlestone, P., \& Stella, M. (2011). Consumer Behavior: Women and Shopping. New York: Business Expert Press. https://doi.org/10.4128/9781606491683

Iqani, M. (2012). Consumer Culture and the Media. Magazines in the Public Eye. New York: Palgrave Macmillan. https://doi.org/10.1057/9781137272133

Jackson, T., \& Shaw, D. (2009). Mastering Fashion Marketing. New York: Palgrave Macmillan. https://doi.org/10.1007/978-1-137-09271-7

Jagger, E. (2000). Consumer Bodies. In P. Hancock (Ed.), The Body, Culture and Society (p. 46). Philadelphia, PA: Open University Press.

Küçükerdoğan, R. (2009). Reklam Nasıl Çözümlenir? İstanbul: Beta Basım. 
Live Japan Perfect Guide (2019). Red Lips, White Face: The Cultural History of Japanese Beauty.

https://livejapan.com/en/in-tokyo/in-pref-tokyo/in-tokyo train station/article-a00012 $\underline{92}$

Madan, S., Basu, S., Ng, S., Ai, E., \& Lim, C. (2018). Impact of Culture on the Pursuit of Beauty: Evidence from Five Countries. Journal of International Marketing, 26, 54-68. https://doi.org/10.1177/1069031X18805493

Maxwell, J. A. (2018). Nitel Araştırma Tasarımı. Etkileşimli Bir Yaklaşım (Translator: Mustafa Çevikbaş). Ankara: Nobel Akademik Yayıncılık Eğitim Danışmanlık.

McAllister, M. P. (2003). Is Commercial Culture Popular Culture? A Question for Popular Communication Scholars. Popular Communication, 1, 41-49.

https://doi.org/10.1207/S15405710PC0101 6

Merriam, S. B. (2018). Nitel Araştırma Desen ve Uygulama İçin Bir Rehber (Translator: Selahattin Turan). Ankara: Atlas Akademik Basım Yayın Dağıtım.

Mooij, M. D. (2004). Consumer Behavior and Culture. Consequences for Global Marketing and Advertising. Thousand Oaks, CA: Sage Publications.

Nash, R., Fieldman, G., Hussey, T., Leveque, J. L., \& Pineau, P. (2006). Cosmetics: They Influence More than Caucasian Female Facial Attractiveness. Journal of Applied Social Psychology, 36, 493-504. https://doi.org/10.1111/j.0021-9029.2006.00016.x

Odabaşı, Y. (1999). Tüketim Kültürü. Yetinen Toplumun Tüketim Topluma Dönüşümü. İstanbul: Sistem Yayınc1lı.

Paterson, M. (2006). Consumption and Everyday Life. New York, NY: Routledge. https://doi.org/10.4324/9780203001769

Pompper, D. (2017). Rhetoric of Femininity. Female Body Image, Media, and Gender Role Stress/Conflict. London: Lexington Books.

Reilly, A. (2014). Key Concepts for the Fashion Industry. London: Bloomsbury Academic.

Richardson, N., \& Locks, A. (2014). Body Studies. New York: Routledge.

Rudd, N. A. (1997). Cosmetics Consumption and Use among Women: Ritualized Activities that Construct and Transform the Self. Journal of Ritual Studies, 11, 59-77.

Russell, R. (2012). Cosmetics Use: Psychological Perspectives. In T. Cash (Ed.), Encyclopedia of Body Image and Human Appearance (Vol. 1, pp. 366-371). Cambridge, MA: Academic Press. https://doi.org/10.1016/B978-0-12-384925-0.00058-4

Schroeder, J. E. (2002). Visual Consumption. New York: Routledge. https://doi.org/10.4324/9780203471630

Stillerman, J. (2015). The Sociology of Consumption. A Global Approach. Cambridge: Polity Press.

Strahle, J., \& Hohls, R. (2018) Fashion and Music. Singapore: Springer Nature. https://doi.org/10.1007/978-981-10-5637-6

Yurchisin, J., \& Johnson, K. K. P. (2010). Fashion and the Consumer. New York: Berg. 